\title{
Human resource management as a profession in South Africa
}

\author{
Authors: \\ Huma van Rensburg \\ Johan S. Basson ${ }^{2}$ \\ Nasima M.H. Carrim² \\ Affiliations: \\ ${ }^{1}$ South African Board for \\ People Practices, \\ South Africa \\ ${ }^{2}$ Department of Human \\ Resource Management, \\ University of Pretoria, \\ South Africa \\ Correspondence to: \\ Nasima Carrim \\ Email: \\ Nasima.carrim@up.ac.za \\ Postal address: \\ Private Bag X20, Hatfield \\ 0028, Pretoria, South Africa \\ Dates: \\ Received: 02 Nov. 2010 \\ Accepted: 23 Mar. 2011 \\ Published: 30 Aug. 2011 \\ How to cite this article: \\ Van Rensburg, H., Basson, J., \\ \& Carrim, N. (2011). Human \\ resource management as a \\ profession in South Africa. SA \\ Journal of Human Resource \\ Management/SA Tydskrif vir \\ Menslikehulpbronbestuur, \\ 9(1), Art. \#336, 15 pages. \\ doi:10.4102/sajhrm.v9i1.336
}

(C) 2011. The Authors. Licensee: AOSIS OpenJournals. This work is licensed under the Creative Commons Attribution License.
Orientation: Various countries recognise human resource (HR) management as a bona fide profession.

Research purpose: The objective of this study was to establish whether one could regard HR management, as practised in South Africa, as a profession.

Motivation for the study: Many countries are reviewing the professionalisation of HR management. Therefore, it is necessary to establish the professional standing of HR management in South Africa.

Research design, approach and method: The researchers used a purposive sampling strategy involving 95 participants. The researchers achieved triangulation by analysing original documents of the regulating bodies of the medical, legal, engineering and accounting professions internationally and locally as well as the regulating bodies of HR management in the United Kingdom (UK), the United States of America (USA) and Canada. Seventyeight HR professionals registered with the South African Board for People Practices (SABPP) completed a questionnaire. The researchers analysed the data using content analysis and Lawshe's Content Validity Ratio (CVR).

Main findings: The results confirm that HR management in South Africa adheres to the four main pillars of professionalism and is a bona fide profession.

Practical/managerial implications: The article highlights the need to regulate and formalise HR management in South Africa.

Contribution/value-add: This study identifies a number of aspects that determine professionalism and isolates the most important elements that one needs to consider when regulating the HR profession.

\section{Introduction}

The professional standing of human resource management is in the spotlight worldwide. An example of this is the very recent formalisation of professional human resource management standards in countries like Canada and Germany.

The South African Board for People Practices (SABPP) drafted the Human Resource Professions Bill in 2004 and revised it in 2006.

It initiated much discussion about the merits of regulating the human resource (HR) profession. One of the key points raised in these debates is whether one can regard HR management as a profession. Losey $(1997$, p. 147) states that 'human resource management is a profession'. Ulrich and Eichinger (1998) maintain that 'HR must become more professional'. Numerous researchers in the HR field (Armstrong, 2000; Losey, Meisinger \& Ulrich, 2005; Ulrich \& Brockbank, 2005) and various institutions (Harvard, Cornell, and the American Business Association) use the term 'HR professionals' in their writings. Human resource management as a profession in South Africa uses Huma van Rensburg's (2009) MCom dissertation as its basis.

\section{Background to the study}

The researchers describe the background to the study in terms of the factors that affect the basic premise under investigation: that one can regard human resource management as a bona fide profession. This study is set against a backdrop of globalisation and a changing economic environment that have a significant effect on the human resources field. 
Before expounding on the background factors, it is necessary to define the term 'profession' and then to explain the concept of 'professionalisation'. The question that one needs to answer is: 'what is a profession and what is professionalism in the context of the current study?'

Abdulla and Threadgold (2010) posit that 'profession' is a term that describes a domain of expertise. Harrison (2007), on the other hand, argues that there has been much debate and confusion about defining the term.

In the past, the term 'profession' applied to law, medicine, engineering, business and academics. These days it is used more freely in different contexts.

There are many definitions of 'profession'. An example is:

a profession is a vocation ... founded upon an understanding of the theoretical structure of some department of learning or science, and upon the abilities accompanying such understanding ... applied to the vital practical affairs of man. The practices ... are modified by knowledge of a generalized nature and by the accumulated wisdom and experience of mankind ... The profession ... considers its first ethical imperative to be altruistic to the client.

(Maudsley \& Strivens, 2000, p. 535)

Another definition is:

Profession means, in its etymological roots, to declare aloud, to proclaim something publicly. On this view professionals make a 'profession' of a specific kind of activity and conduct to which they commit themselves and to which they can be expected to conform. The essence of a profession then is this act of 'profession' - of promise, commitment and dedication to an ideal.

(Pellegrino, 2002, p. 379)

During the 1970s, Freidson said that the term 'profession' was founded on independent practice, self-auditing processes, expert knowledge and special value in its work, as well as monopoly and service to the public. Around the same time, Hall suggested that professions start with a professional model, its accompanying attributes and profession-specific content (Williams, Onsman \& Brown, 2009).

'Professionalisation', on the other hand, is a method of making a developing occupation socially legitimate. In the course of forming and defining itself, an occupational group must construct and maintain occupational boundaries that consist of social or cultural divisions that help to indicate a group's work, societal roles and legitimacy (Lauk \& Pallas, 2008). The boundary activities consist of defining specific work tasks and normative occupational values, determining professional standards, influencing education and recruiting new members. A professional organisation gets the legal right to control its field and opposes external interference to control the activities of the occupation's constituents (Lauk \& Pallas, 2008).

Therefore, professionalisation is the profession's ability to convince legislators and society that its work is significant (Williams, Onsman \& Brown, 2009).
According to Williams, Onsman and Brown (2009), professionalisation progresses linearly towards acquiring a number of essential characteristics like codes of ethics, professional associations and specialised skills. Professions should move through four stages, in chronological order, during the process of professionalising:

- creating full-time occupations

- establishing training schools

- establishing professional bodies

- developing codes of ethics.

Abdulla and Threadgold (2010) and Wilensky summarised the process of professionalising as:

- developing the occupation into a full-time one and creating occupational territory

- establishing training schools or colleges and linking these to universities

- promoting the occupation to national and international parties

- obtaining professional licences and accreditation

- developing a code of ethics.

This article has outlined the stages and processes of professionalising. It now describes the five factors that affect the drive towards professionalising the human resource field in South Africa.

The first factor is an increased awareness, internationally and in South Africa, of the necessity for ethical conduct in business (Dixon, 2006; Ndlovu, 2006). Following the major governance issues the first King report covers, the second report emphasised values, conduct, fairness, accountability, responsibility and transparency in corporate governance. King emphasised regulating the human resource environment in order to ensure compliance with suitable codes of conduct. King saw enforcing codes of conduct as the basic requirement for good practice.

The second factor is the current drive towards professionalising human resource management in South Africa and the increasing burden of compliance with legislative requirements. It is largely the responsibility of human resource practitioners to implement labour legislation in organisations. This environment requires an understanding and knowledge of the legislation as well as the competence to introduce the correct measures in the workplace. It is an area of HR management that requires specialised and continually updated knowledge, expertise and competence (Cohen, 2005).

The third factor is the need for a recognised body of knowledge and standards of conduct in the practice of human resource management. This was identified in South Africa in the late seventies. Paradoxically, the heart of the problem is the professional status of human resource management, which this study tackles. People from all walks of life are practising human resource management. Meisinger (2006) stated that many who practise HR management are not HR professionals. This affects the perception of HR management. 
The number of applications for professional registration the SABPP has received from people with widely diverse backgrounds illustrates this as well. Some people practise HR management without any formal training. This does not happen in other major profession, where a qualification is a minimum requirement for entry.

Companies, which redirect employees who are unsuccessful in other departments into their human resource departments, may create these various entry points from other disciplines. In a recent conversation at a local government seminar in South Africa, delegates called this practice 'dumping'. This has a devastating effect on the general levels of the competence of the people in human resource management and on its perceived lack of stature.

The fourth factor that influences this study of human resource management as a profession is a quality management system for education and training for South Africa that the South African Qualifications Authority (SAQA) Act No 58 of 1995 has introduced.

This has raised national awareness of the need for acceptable standards and for measuring or controlling the quality of education and training on a much wider scale than was attempted before in South Africa. Applicants who have a formal and relevant qualification, together with a number of years of experience at a specified level of practice, are registered as HR professionals in South Africa. Recognition of prior learning (RPL) is another effective route for registration.

The SABPP is the recognised standards body for human resource management. It has been the accredited Education and Training Quality Assurance (ETQA) body for Human Resource Management and Practice, Human Resource Development (HRD) and Skills Development Facilitation (SDF), Productivity and Disability Employment Practice since November 2002. Reaccreditation until September 2011 has confirmed the status of the SABPP as the professional body and the ETQA for human resource management in South Africa.

The fifth factor is the South African government's increased awareness of the value of professionalism in increasing productivity and decreasing corruption. The SABPP is currently collaborating with the Local Government Leadership Academy working group to promote the professionalisation of human resource management in South Africa.

\section{Research objective}

The purpose of the study is to establish whether human resource management, as practised in South Africa, is a profession.

In order to achieve this objective, the researchers:

- analysed the original documents of the four widely acknowledged professions in South Africa, namely the legal, engineering, medical and accounting professions, to identify the principles of professionalism and ethical conduct of these professions

- examined the original documents of the regulating bodies of HR management in three countries, namely the Chartered Institute of Personnel and Development (CIPD) in the UK, the Human Resource Certification Institute (HRCI) in the USA and the Canadian Council of HR Associations (CCHRA) to identify the principles, values and ethical conduct matters they regard as important for establishing HR management as a profession in their respective countries

- conducted interviews with selected HR mentors of the SABPP to identify the important conduct matters and values of HR management as a profession in South Africa

- tested the validity of the information they acquired from registered HR practitioners in South Africa.

\section{Research design Research approach}

The ontological approach the researchers used in this study focused on the views of professional bodies and HR professionals about the professional principles and conduct of professions in general and particularly of HR managers in South Africa.

The researchers were aware that the participants' contributions were based on their understanding and interpretation of what constitutes principles and professional conduct in HR management.

The researchers decided to use the interpretivist approach to understand and verify the dynamics of the challenge in question, which is to make HR management a profession, by identifying, understanding and interpreting the participants' perceptions of the principles and conduct of HR professionals.

\section{Research strategy}

The researchers combined qualitative and quantitative research strategies by using the original documents of professional bodies, semi-structured interviews with mentors and a questionnaire.

The researchers achieved triangulation using the techniques that follow.

Firstly, the study focused on the original documents of the regulating bodies of international and South African medical, legal, engineering and accounting professions and the regulating bodies of HR management in the UK, USA and Canada. The researchers did so to identify the principles of professionalism and ethical conduct these professions embrace.

Secondly, the researcher conducted semi-structured interviews with 15 mentors from the SABPP to ascertain what they believed were the principles of professionalism and ethical conduct of HR managers in South Africa. 
Lastly, the researchers used a questionnaire to verify the information they received in the interviews and from their analysis of documents from the regulating bodies. They sent the questionnaire to HR professionals registered with the SABPP.

\section{Research method Research setting}

The researchers chose mentors registered as Chartered or Master HR practitioners with the SABPP to get their views on the current state of HR management in South Africa. These mentors are from different provinces in South Africa. The researchers also sent questionnaires to HR professionals registered with the SABPP who are from different provinces in South Africa.

\section{Entrée}

One of the researchers is CEO of the SABPP and knows which senior mentors in this field could contribute to the study. This researcher had access to the contact details of the mentors and had contacted the mentors personally to explain the aim of the study and to obtain permission to interview them. The researchers also had the contact details of the HR practitioners and had emailed the questionnaire to those HR practitioners registered with the SABPP.

\section{Sampling}

The researchers used purposive sampling to select the research participants. They chose fifteen mentors (who were Chartered or Master HR practitioners) for their indepth knowledge of HR management in South Africa. The researchers decided to use the list of HR professionals registered with the SABPP to delineate the group they would use to verify the data they obtained from the original documents of the professional bodies and the information the mentors provided. They received 79 responses. Of the responses they received, just more than half $(57 \%)$ of the respondents were men and $43 \%$ were women.

\section{Data collection}

The researchers collected data from four sources. These were the original documents of the regulating bodies of the medical, legal, engineering and accounting professions, the SABPP in South Africa and the regulating bodies of HR management in the UK, USA and Canada. They also collected data from their semi-structured interviews and the verification questionnaire. Their data collection methods follow.

The researchers decided to obtain original documents from the regulating bodies and the SABPP because they could conduct reliable analyses of these documents to get an indepth understanding of the values and conduct issues that underpin the different professions and the HR profession in four countries.

The researchers conducted semi-structured interviews with senior mentors because they could provide an in- depth understanding of conduct issues and values in HR management in South Africa.

The researchers sent a questionnaire to HR professionals because the nature of their work meant that they could verify whether the ethical professional issues the researchers identified are relevant and should be a part of the regulating mechanisms of HR professionals in South Africa. The HR professionals had to complete questions on a three-point Likert scale and indicate whether certain professional conduct issues were 'essential', 'useful but not essential' or 'not necessary' for regulating the HR profession.

A panel of experts in the field of HR management developed the research questionnaire titled 'Determining the ethical professional conduct issues in the HR field'. The researchers used it as the third leg of triangulation in the study because the questionnaire already contained many of the conduct and ethical issues they identified from the original documents and semi-structured interviews.

The questionnaire covered six categories:

- basic personal values

- desirable professional qualities

- responsibility towards the profession

- responsibility towards clients or employers

- responsibility towards the public or society

- personal work ethics

- knowledge and skills to operate as a professional in the field of HR management.

\section{Data capture}

The researchers examined documents from the various regulating bodies and the SABPP. They conducted recorded interviews. They sent emails to the participants who were to complete the questionnaire. The reason for this was to get data from participants who were dispersed geographically. The researchers then transcribed the recorded interviews. The participants returned the questionnaires by email. The researchers printed the completed questionnaires and analysed the answers statistically.

\section{Data analysis}

The researchers used content analysis to extract themes from the original documents of the regulating bodies and from the semi-structured interviews. Content analysis includes coding and classifying data (Hancock, 2002).

According to Trochim (2006), coding is a process of categorising qualitative data and of describing the implications and details of these categories. Open coding created new codes for the transcripts and the original documents of the regulating bodies. The researchers had identified a list of categories from the transcripts and initially used open coding to identify certain themes.

After the researchers had used open coding for all new themes, they used list-by-codes for all subsequent documents 
that had the same recurring themes. The researchers also used quick coding as one can use this method for consecutive coding of segments using the same code (Muhr, 1997).

In their analysis of the data they obtained from the questionnaire, the researchers calculated Lawshe's CVR (1975). The CVR is an item statistic that is useful in rejecting or retaining specific items. Using this approach, subject experts (HR practitioners) indicated whether certain professional conduct issues were 'essential', 'useful but not essential' or 'not necessary' for regulating the HR profession. The researchers then used the inputs from the subject experts to compute the CVR.

\section{Strategies used to ensure quality data}

When conducting qualitative research, researchers have to ensure the credibility, transferability, confirmability and dependability aspects of the research.

According to Mackey and Gass (2005), because qualitative research can use the assumption of multiple constructed realities, it is vital for qualitative researchers to assure their research peers that their findings are credible. The researchers used semi-structured interviews as well as a questionnaire to add credibility to the study.

In terms of transferability in qualitative research, Mackey and Gass (2005) see the context as important. Although one does not really transfer the findings of qualitative research from one context to another, the extent to which one may transfer findings depends on the similarity of the context. When determining the similarity of findings, researchers use rich descriptions. These use several perspectives to explain the insights researchers gain from the research and to consider the viewpoints of the participants. The reason for using rich descriptions is that, if the researchers discuss the findings in enough detail, other researchers will understand the context and be able to compare the research situation with their own and determine which findings they can transfer to theirs. Other researchers in a similar context can then use some of the professional and ethical conduct issues the researchers discovered in the current research.

Confirmability deals with reliable knowledge, checked and controlled, and undistorted by personal bias and prejudice (Kvale, 1996). Qualitative researchers should give full details of the findings they use to make claims. The reason is that other researchers can confirm, modify or reject the first researchers' interpretations (Mackey \& Gass, 2005). The current study allowed the subject experts to confirm whether the professional conduct issues the researchers identified are relevant for regulating the HR profession in South Africa.

Dependability emphasises that researchers need to account for the ever-changing context within which research occurs. Researchers are responsible for describing the changes that occur in the context and how these changes affect the way the researchers approach the study (Trochim, 2006). The asked the participants to review the researchers' interpretations in the current research.

\section{Findings}

The researchers reviewed the literature on the engineering, accounting, medical and legal professions and established that all recognised major professions had four core elements in common. Figure 1 gives the four pillars of professionalism.

Pillar 1: mastery of a complex body of knowledge and skills. Professional boards accredit the curricula of training institutions before professionals can register with these boards. Therefore, the cornerstone of professionalism is knowledge and skills. Each of these professions has specific guidelines for the knowledge and skills people need to have if they want to become professionals. Academic and other training institutions use these guidelines when developing their curricula for accreditation by professional bodies.

Pillar 2: commitment to integrity and morality through a code of conduct. This pillar was vital to all the professions. The emphasis in all the professions was on how professionals should behave in broader society whilst maintaining the integrity of their professions.

Pillar 3: autonomy in practice and the privilege of selfregulation. This pillar was common to all the professions. It implies that it is essential for professionals to be autonomous in their work.

Pillar 4: acceptance of a duty to society as a whole. There is a duty to society in all the professions. None of these professions can operate in isolation.

The researchers developed and numbered tables from these pillars.

Table 1 gives an overview of the structure of these professions in South Africa and shows how each profession regulates entry. An analysis of the original documents shows that all the professions have regulating bodies, professional titles, requirements for accreditation, for internship, experience and for continuous professional development (CPD), codes of ethics and applicable laws. In all cases, an academic qualification is the starting point of a career. All have a period of training that happens with the supervision the

\begin{tabular}{|ll|}
\hline Pillar number & Name of pillar \\
\hline 1 & Mastery of a complex body of knowledge and skills. \\
2 & $\begin{array}{l}\text { Commitment to integrity and morality through a } \\
\text { code of conduct. } \\
\text { Autonomy in practice and the privilege of self- } \\
\text { regulation. }\end{array}$ \\
4 & Acceptance of a duty to society as a whole. \\
\hline
\end{tabular}

FIGURE 1: The four pillars of professionalism. 
individual bodies require. Finally, they require examinations or professional reviews that laws determine.

Human resource management has a regulating body, a qualification requirement, an experience component and a professional peer review requirement before registration, a code of conduct and a structured CPD process. No law recognises its professional status at the moment.

The researchers recorded the conduct issues (including values) they found in the literature of each of the four professions in Table 2 to compile a database of the issues that each of the professions emphasise in their writings and codes.

The only three values in Table 2 that all of the professions hold, although they express them differently, are 'sound moral character' (ethical conduct), 'maintaining the good reputation and prestige of the profession' (self-regulation) and 'mastering the particular intellectual skills of the profession acquired by training and education' (knowledge and skills). This confirms the pillars the researchers identified. Other values the professions rate highly imply the fourth pillar ('acceptance of a duty to society'). They are 'respect for human dignity' and 'confidentiality'. 'Acting as a faithful agent', 'adopting responsible behaviour', 'respecting the rights of others' and 'objectivity' all imply a concern for the public or clients.

Professions are clearly sensitive about their reputations. Perception plays a major role in how the public and the media view professions. The professions also recognise the importance of updating information, skills and competence continually. Finally, the professions rate 'maintaining confidentiality' highly as a professional value.

From the researchers' analysis of the original documents of the four professions, the following concerns emerged about professional practice in a modern context:

- professions and professionals often have to defend their professional judgements and their positions of independence in the face of corporate greed and require professionals to have inner strength

- there is a general concern that a decline in 'old-fashioned' mores, like honesty, integrity and honour, might affect professionalism

- professionals often have to share their responsibility with other, perhaps less rigorously regulated or ethically sensitised parties, like employers, clients and other stakeholders

- self-regulation does fail at times, leaving the public with the perception that professions sometimes protect their members and not the public

- there is an increased loss of control over basic professional decisions, that the state, the corporate sector or others have taken over

- there is not enough research on compliance with codes of conduct.

The researchers qualitatively analysed the core results of the interviews with mentors of the SABPP on their views on present-day HR management. A major theme that emerged from these interviews is a deep concern about the reputation of HR managers. This links directly to incompetent people in practice.

Professionalising HR management will go some way towards solving many of the issues. An acceptance, by industry, of the standards the professional body sets may help to improve standards of practice even more.

The interview questions the researchers posed to the mentors produced, in essence, the answers that follow.

\section{Question 1: How important is the competency of HR professionals in giving the organisation a leading edge?}

Most respondents believed that the role of HR managers is becoming increasingly important. Factors that influence this view were:

- international competitiveness

- increased productivity requirements

- retaining young talent or highly talented practitioners

- that knowledge property is becoming the most significant competitive edge

- a recurring skills shortage that requires intervention

- that governments increasingly require competent and strategic HR services.

TABLE 1: Regulatory frameworks of the legal, engineering, medical and accounting professions in South Africa.

\begin{tabular}{|c|c|c|c|c|}
\hline Regulatory frameworks & Legal & Engineering & Medical & Accounting \\
\hline Regulating body & General Council of the Bar & $\begin{array}{l}\text { Engineering Council of South } \\
\text { Africa }\end{array}$ & $\begin{array}{l}\text { Health Professions Council of } \\
\text { South Africa and professional } \\
\text { boards }\end{array}$ & $\begin{array}{l}\text { South African Institute of } \\
\text { Chartered Accountants }\end{array}$ \\
\hline Professional title & Advocate & Civil engineer & Clinical/medical psychologist & Accountant \\
\hline $\begin{array}{l}\text { Requirements for } \\
\text { accreditation }\end{array}$ & Bar examination & Professional review & $\begin{array}{l}\text { National examination of the } \\
\text { board }\end{array}$ & $\begin{array}{l}\text { Two CTA (Certificate in Theory } \\
\text { of Accounting) examinations }\end{array}$ \\
\hline $\begin{array}{l}\text { Internship or } \\
\text { experience required }\end{array}$ & One year & $\begin{array}{l}\text { Training to the Engineering } \\
\text { Council of South Africa (ECSA) } \\
\text { schedule }\end{array}$ & One-year internship & $3-5$ years \\
\hline CPD & Required & Required & Required & Required \\
\hline Code of ethics & Yes & Yes & Yes & Yes \\
\hline Applicable Laws & $\begin{array}{l}\text { Admission of Advocates Act } 74 \text { of } \\
1964\end{array}$ & $\begin{array}{l}\text { Engineering Profession Act } 46 \\
\text { of } 2000\end{array}$ & Health Professions Act 56 of 1974 & $\begin{array}{l}\text { The Public Accountants and } \\
\text { Auditors Act No } 80 \text { of } 1991\end{array}$ \\
\hline
\end{tabular}


TABLE 2: Overarching comparative matrix of conduct issues.

\begin{tabular}{|c|c|c|c|c|c|c|c|c|}
\hline \multirow{2}{*}{$\begin{array}{l}\text { Conduct issues } \\
\text { (values and ethics included) }\end{array}$} & \multicolumn{4}{|c|}{ The four major professions } & \multicolumn{4}{|c|}{ Professional bodies in the field of HR management } \\
\hline & Legal & Engineering & Medical & Accounting & $\begin{array}{l}\text { CIPD } \\
\text { (UK) }\end{array}$ & $\begin{array}{l}\mathrm{HRCl} \\
\text { (USA) }\end{array}$ & $\begin{array}{l}\text { CCHRA } \\
\text { (Canada) }\end{array}$ & $\begin{array}{c}\text { SABPP } \\
\text { (South Africa) }\end{array}$ \\
\hline $\begin{array}{l}\text { Maintaining the good reputation and prestige of the } \\
\text { profession }\end{array}$ & $v$ & 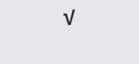 & $\mathrm{V}$ & $v$ & $\checkmark$ & - & - & $\checkmark$ \\
\hline Improving and growing the profession & - & v & - & - & - & - & - & 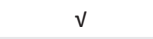 \\
\hline $\begin{array}{l}\text { Maintaining the highest standards of professional } \\
\text { conduct }\end{array}$ & $v$ & - & $v$ & $v$ & - & $\checkmark$ & - & $v$ \\
\hline $\begin{array}{l}\text { Not permitting motives of profit to influence the } \\
\text { independent exercise of professional judgement }\end{array}$ & $v$ & - & $\checkmark$ & - & - & - & - & - \\
\hline $\begin{array}{l}\text { Adhering to the common code of values and conduct } \\
\text { of the profession }\end{array}$ & $v$ & $\checkmark$ & $v$ & - & - & - & - & $v$ \\
\hline Supporting the system to allow for quality entrants & - & - & - & - & - & - & - & - \\
\hline Dedication to service or pro bono service & $v$ & - & - & - & - & v & - & - \\
\hline Acceptance of duty to society as a whole & - & - & - & $v$ & - & - & - & v \\
\hline
\end{tabular}

of the public

Serving with fidelity the public, employees and

clients

Promoting the public good and development of

people

Willing to subordinate self-interest in pursuit of

public service

Acting in the client's interest

Certifying only what has been personally verified

Maintaining and improving work systems

Prepared to assume responsibility for effect of a task

Acting as faithful agent or trustee in all circumstances

A dedication to providing competent service

Promoting justice and fairness

Avoiding conflict of interest

Adopting responsible behaviour

Respecting the rights of others

Maintaining an outlook which is essentially objective

Rendering service in accordance with the relevant

technical and professional standards

Building professional reputation on the quality of

services rendered

Issuing public statements only in an objective and

truthful manner

Playing a positive and constructive role where

deviation from reputable practices occur

Mastery of the particular intellectual skills of the profession acquired through training and education

Continued concern for professional competence

Recognising personal limitations and consulting with

other experts

Keeping up to date with developments in practice,

legislation and techniques

Continuing to develop professional knowledge and

skill throughout career

Sound moral character (integrity, honour and

honesty)

Respect for human dignity

Confidentiality

Loyalty to profession

Concern for research

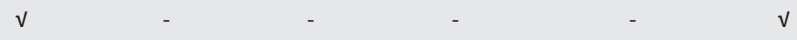

CIPD, Chartered Institute of Personnel and Development; HRCl, Human Resource Certification Institute; CCHRA, Canadian Council of HR Associations; SABPP, South African Board for People Practices.

\section{Question 2: Is there an awareness of the importance of the professionalisation of HR?}

The researchers ascertained that professionalising HR management is vital worldwide. The interviewees emphasised that organisations regard HR management more highly these days than they did before. One respondent made the point that, if the HR executive of a company is not truly professional, the rest of the company will follow. A dilemma in the professionalisation of HR management is that there is no consensus amongst HR professionals about 
TABLE 3: Descriptive statistics of basic personal values of professionals.

\begin{tabular}{|c|c|c|c|c|c|c|}
\hline \multirow[t]{2}{*}{ Identifying elements } & \multicolumn{3}{|c|}{ Descriptives } & \multicolumn{3}{|c|}{ Lawshe frequencies of items } \\
\hline & $N$ & Mean & SD & $\begin{array}{c}\text { Perceived as } \\
\text { 'essential' }\end{array}$ & $\begin{array}{l}\text { Perceived as 'useful } \\
\text { but not essential' }\end{array}$ & $\begin{array}{c}\text { Perceived as 'not } \\
\text { necessary' }\end{array}$ \\
\hline Sound moral character & 79 & 4.6709 & 0.61439 & 73 & 6 & 0 \\
\hline Respect for human dignity & 78 & 4.5897 & 0.69199 & 71 & 6 & 1 \\
\hline Altruism & 78 & 3.9103 & 1.02166 & 55 & 14 & 9 \\
\hline Loyalty & 78 & 3.8077 & 1.06975 & 51 & 17 & 10 \\
\hline Concern for development and progress & 78 & 4.2436 & .0 .80881 & 62 & 15 & 1 \\
\hline
\end{tabular}

$\mathrm{SD}$, denotes standard deviation; $N$, denotes number of respondents.

the scope of HR management and the practical fields that HR management should include. This contrasts with the agreement that doctors, lawyers and accountants have.

\section{Question 3: What about accountability and ethical conduct?}

There was consensus that this was an area of deep concern amongst the respondents. They made these points:

- leading HR practitioners who act dishonestly or incompetently do untold damage

- accountability is one of the main concerns amongst organisations in South Africa

- codes of conduct are critical and organisations must internalise them

- communication, training and investment are necessary

- senior people must 'walk the talk'.

\section{Question 4: Comment on a vision for HR in South Africa?}

Strong views emerged here. Senior HR practitioners are clearly passionate and deeply concerned about the role of $\mathrm{HR}$ managers. The made these main points:

- the HR profession needs regulation of one form or another

- HR management has an important contribution to make toward sound corporate governance

- organisations should focus on training and development and on retaining talent

- organisations should train and develop HR people so that they can function as professionals

- universities must become involved in professionalising HR management.

From their literature analysis of original documents, the interviews they conducted with mentors of the profession and in the light of the professional pillars they identified, the researchers concluded that HR management is indeed a profession.

Based on their findings from the current research, the researchers concluded that it is vital that HR management becomes professionalised and that certain areas where problems exist in the process of professionalising are addressed.

\section{Survey findings}

The core findings of the survey are that the HR community in South Africa also sees the elements, which the researchers identified, as important for building and regulating the HR profession. Tables 3-14 contain these results.

Tables 3 and 4 deal with the basic personal values of professionals. Respondents had to consider the importance of each value in the light of what constituted good governance in a profession.

The respondents regarded 'sound moral character' and 'respect for human dignity' as the most important personal values for an HR professional. This corresponds to the values that all the other professions (see Table 2) and the literature (Robert, 2004) see as imperative in. King III confirms that good governance is about 'responsible leadership, which calls for integrity, transparency and accountability' (Temkin, 2009).

Related to the personal values of professionals are the qualities that are most desirable in a profession. Tables 5 and 6 give these.

Tables 5 and 6 deal with desirable professional qualities. Respondents rated all the qualities highly. However, in the current climate, with its heightened awareness of the erosion of moral values, the qualities the respondents valued most are 'credibility' and 'accountability'. This coincides with the results of the qualitative analysis of the four major professions, where 'a commitment to integrity and morality through a code of conduct' was a principle (the second pillar) of professionalism.

The respondents also valued 'discretion', 'intellectual honesty' and 'good judgement' highly as qualities a professional should have. They correspond to the principle of 'autonomy of practice and the privilege of self-regulation' (the third pillar). If professionals work in self-regulated

TABLE 4: Content Validity Ratio (Lawshe) of basic personal values of professionals.

\begin{tabular}{llll}
\hline Identifying elements & $\boldsymbol{N}_{\boldsymbol{e}}$ & $\boldsymbol{N}$ & CVR \\
\hline Sound moral character & 73 & 79 & 0.8481 \\
Respect for human dignity & 71 & 78 & 0.8205 \\
Altruism & 55 & 78 & 0.4103 \\
Loyalty & 51 & 78 & 0.3077 \\
Concern for development and progress & 62 & 78 & 0.5897 \\
\hline
\end{tabular}

$N$, denotes number of respondents who indicated 'essential'; $N$, denotes number of respondents; CVR, denotes Content Validity Ratio.

CVR values $>0.2$ are significant at $p 0.05$ 
TABLE 5: Descriptive statistics of desirable professional qualities.

\begin{tabular}{|c|c|c|c|c|c|c|}
\hline \multirow[t]{2}{*}{ Identifying elements } & \multicolumn{3}{|c|}{ Descriptives } & \multicolumn{3}{|c|}{ Lawshe frequencies of items } \\
\hline & $N$ & Mean & SD & $\begin{array}{l}\text { Perceived as } \\
\text { 'essential' }\end{array}$ & $\begin{array}{l}\text { Perceived as 'useful } \\
\text { but not essential' }\end{array}$ & $\begin{array}{c}\text { Perceived as 'not } \\
\text { necessary' }\end{array}$ \\
\hline Leadership qualities & 78 & 4.0897 & 0.94231 & 60 & 13 & 5 \\
\hline Confidence & 77 & 4.0909 & 0.98918 & 56 & 16 & 5 \\
\hline Credibility & 78 & 4.641 & 0.83704 & 72 & 3 & 3 \\
\hline Good judgement & 79 & 4.5063 & 0.8301 & 69 & 8 & 2 \\
\hline Independent functioning & 76 & 4.1974 & 0.92405 & 61 & 11 & 4 \\
\hline Discretion & 77 & 4.4545 & 0.75298 & 69 & 6 & 2 \\
\hline Accountability & 78 & 4.6026 & 0.69019 & 71 & 6 & 1 \\
\hline Understanding of obligations & 76 & 4.0789 & 0.8758 & 58 & 14 & 4 \\
\hline Intellectual honesty & 76 & 4.5263 & 0.72062 & 68 & 7 & 1 \\
\hline
\end{tabular}

$\mathrm{SD}$, denotes standard deviation; $N$, denotes number of respondents.

environments, the public will trust them if they show the qualities of discretion, intellectual honesty and good judgement.

In a professional environment, 'independent functioning' is an indispensable quality and corresponds to the third pillar. The qualitative analysis established that professionals must be able to make independent judgements and defend their viewpoints, in difficult circumstances, in the work environment.

The human resource community sees 'leadership qualities', 'understanding obligations' and 'confidence' as vital qualities for professionals. The last three qualities relate, once again, to the principles of 'autonomy of practice and the privilege of self-regulation' (the second pillar) and an 'acceptance of a duty to society as a whole' (the fourth pillar). Leadership qualities and understanding one's obligations toward one's profession correspond closely to professionals' responsibilities towards their profession.

Tables 7 and 8 give these results.

Tables 7 and 8 cover responsibility towards the profession. The results show that respondents saw 'always maintaining the highest personal standards' as a crucial value. In mastering the subject and practising with integrity, in selfregulating and in accepting a duty to society, only the highest personal standards will gain the respect of the community and improve the profile of the profession. This also corresponds to the personal responsibility of maintaining the currency of knowledge and skills - the rapidly changing environment demands continued professional development and links to 'a mastery of a complex body of knowledge' (the first pillar).

Table 8 shows that 'maintaining the good reputation and prestige of the profession' is another vital value. Because HR management is struggling for recognition as a significant contributor to the economy, it makes this responsibility particularly important. The practice of moving unqualified or incompetent people into HR management, as the qualitative analysis showed, has badly damaged the reputation of human resource managers.

Table 8 identifies 'adhering to a common code of values' (second pillar) as another imperative value. The code of conduct a profession recognises should meet the highest aspirational demands and cover all the important areas of practice. Exposing fraud and deception, working to improve the profession, having the right motives and investing in new entrants will enrich the profession significantly and lift the standard of HR management in general.

These results show that the HR community understands that building a credible profession requires that individual practitioners set the highest possible standards for themselves. The norms and discipline a profession imposes on its members support general ethical practice in the profession. As HR management aspires towards acknowledgement at the same level as the four major professions, it is clear that it needs to do the same. A profession must set and maintain its own standards whether it has statutory recognition or not.

Maintaining high levels of responsibility toward clients or employers is imperative, as tables 9 and 10 show.

Of all the values that correspond to responsibility toward clients or employers, 'a dedication to providing competent service' (see tables 9 and 10) is important. It implies 'a mastery of the complex body of knowledge and skills' (the first

TABLE 6: Content Validity Ratio (Lawshe) of desirable professional qualities.

\begin{tabular}{llll}
\hline Identifying elements & $\boldsymbol{N}_{e}$ & $\boldsymbol{N}$ & CVR \\
\hline Leadership qualities & 60 & 78 & 0.5385 \\
Confidence & 56 & 77 & 0.4545 \\
Credibility & 72 & 78 & 0.8462 \\
Good judgement & 69 & 79 & 0.7468 \\
Independent functioning & 61 & 76 & 0.6053 \\
Discretion & 69 & 77 & 0.7922 \\
Accountability & 71 & 78 & 0.8205 \\
Understanding of obligations & 58 & 76 & 0.5263 \\
Intellectual honesty & 68 & 76 & 0.7895 \\
\hline
\end{tabular}

$N_{e}$, denotes number of respondents who indicated 'essential'; $N$, denotes number of respondents; CVR, donates Content Validity Ratio.

CVR values $>0.2$ are significant at $p 0.05$ 
TABLE 7: Descriptive statistics of responsibility towards profession.

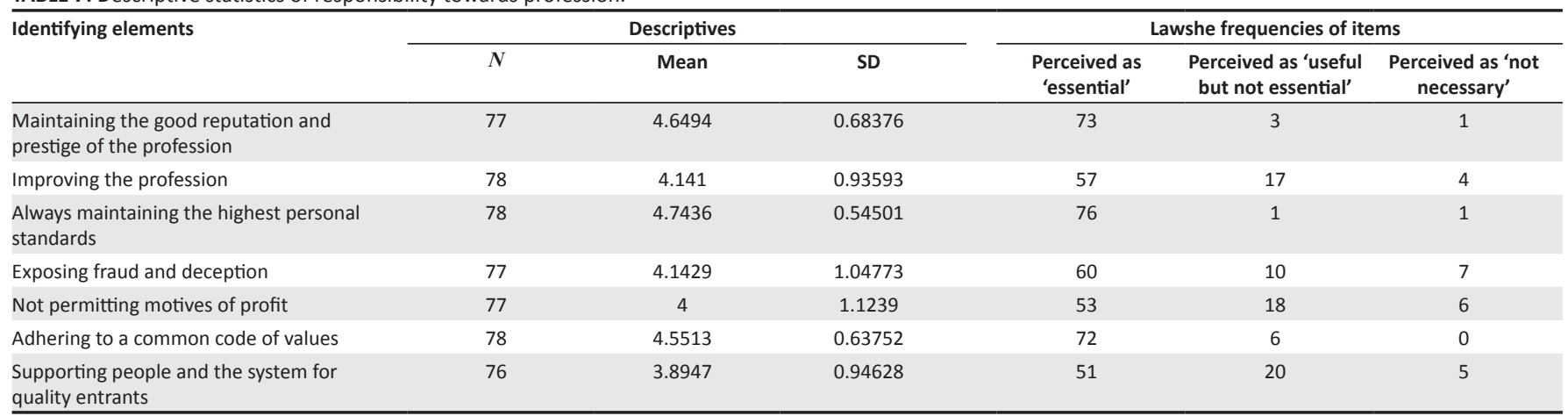

$\mathrm{SD}$, denotes standard deviation; $N$, denotes number of respondents.

pillar). Respondents saw competence as an integral part of being a professional. Providing a competent service includes maintaining currency and growing in understanding of the complexities of the modern economy as the role of HR managers broadens and becomes more strategic. This outcome shows that human resource professionals are aware that this is a serious responsibility, as other professionals are (Williams, 1997).

The second and third values, namely 'acting in the client's interest' and 'acting as a faithful agent', link to the fourth pillar of professionalism: 'acceptance of a duty to society as a whole'. Tables 11 and 12 show that respondents see them as significant. There is also a significant link to a commitment to integrity (the second pillar).

Tables 11 and 12 give low scores for responsibility towards the public or society. This may mean that the HR community sees this as an area for which each manager takes personal responsibility and not as an area for the profession to regulate.

This does not imply that responsibility to society is unimportant. On the contrary, in the previous table a dedication to providing competent service to the client, who is also part of the public or society, has the highest value. As with the other professions, however, the HR practitioner acknowledges a responsibility towards the public and society, firstly through a 'dedication to service' and secondly by 'serving, with fidelity, the public, employees and clients'. In this sense, being a professional is synonymous with an attitude of service (Lewis, 2001) and a high personal work ethic.

Tables 13 and 14 show this.

Tables 13 and 14 cover responsibility for a personal work ethic. It is a value that that HR professionals value highly and regard as significant for upholding the profession. The respondents value 'adopting responsible behaviour' highly. It corresponds to the fourth pillar, which is 'acceptance of a duty to society as a whole'. This shows that the HR community understands the importance of serving the public and society with maturity and sound judgement.

'Rendering service in accordance with standards' is significant because this implies that there are set and recognised standards that the HR community accepts. This correlates with the first pillar, 'a mastery of a complex body of knowledge and skills', where a regulating body defines the knowledge and skills.

Therefore, it is logical to conclude that, unless a profession organises and structures itself and makes decisions about the relevant technical and professional criteria, there will be no standards to provide a measurement. How then will those that reject professional governance even know whether they are meeting the standards? To meet standards, one must surely know what those standards are (Robert, 2004).

In addition to knowing and meeting standards, the HR practitioner must master skills, be aware of personal shortcomings and continuously update skills.

Tables 15 and 16 give the results.

Tables 15 and 16 cover responsibility for knowledge and skills. It corresponds to the first pillar - 'a mastery of a complex body of knowledge and skills'. This pillar, on which all professions build, is pivotal. The first pillar the researchers

TABLE 8: Content Validity Ratio (Lawshe) of responsibility towards profession.

\begin{tabular}{|c|c|c|c|}
\hline Identifying elements & $N_{e}$ & $N$ & CVR \\
\hline $\begin{array}{l}\text { Maintaining the good reputation and prestige of } \\
\text { the profession }\end{array}$ & 73 & 77 & 0.8961 \\
\hline Improving the profession & 57 & 78 & 0.4615 \\
\hline $\begin{array}{l}\text { Always maintaining the highest personal } \\
\text { standards }\end{array}$ & 76 & 78 & 0.9487 \\
\hline Exposing fraud and deception & 60 & 77 & 0.5584 \\
\hline Not permitting motives of profit & 53 & 77 & 0.3766 \\
\hline Adhering to common code of values & 72 & 78 & 0.8462 \\
\hline $\begin{array}{l}\text { Supporting people and the system for quality } \\
\text { entrants }\end{array}$ & 51 & 76 & 0.3421 \\
\hline
\end{tabular}

$N_{e}$, denotes number of respondents who indicated 'essential'; $N$, denotes number of respondents; CVR, denotes Content Validity Ratio.

CVR values $>0.2$ are significant at $p 0.05$ 
TABLE 9: Descriptive statistics of responsibility towards client or employer.

\begin{tabular}{|c|c|c|c|c|c|c|}
\hline \multirow[t]{2}{*}{ Identifying elements } & \multicolumn{3}{|c|}{ Descriptives } & \multicolumn{3}{|c|}{ Lawshe frequencies of items } \\
\hline & $N$ & Mean & SD & $\begin{array}{c}\text { Perceived as } \\
\text { 'essential' }\end{array}$ & $\begin{array}{l}\text { Perceived as 'useful } \\
\text { but not essential' }\end{array}$ & $\begin{array}{c}\text { Perceived as 'not } \\
\text { necessary' }\end{array}$ \\
\hline Acting in client's interest & 77 & 4.2857 & 0.99812 & 66 & 6 & 5 \\
\hline Certifying and authorising & 74 & 3.9189 & 1.00351 & 52 & 16 & 6 \\
\hline Maintaining and improving integrity & 75 & 3.88 & 1.02614 & 51 & 17 & 7 \\
\hline Assume responsibility for effect of task & 75 & 3.9867 & 1.07167 & 52 & 16 & 7 \\
\hline Not enticing clients away from colleagues & 74 & 3.9324 & 1.10207 & 50 & 17 & 7 \\
\hline Acting as faithful agent & 75 & 4.28 & 0.89382 & 62 & 10 & 3 \\
\hline Dedication to providing competent service & 76 & 4.5658 & 0.67991 & 73 & 25 & 3 \\
\hline
\end{tabular}

SD, denotes standard deviation; $N$, denotes number of respondents.

identified also implies that professionals and the profession should recognise and subscribe to this body of knowledge.

It is also vital for the health of a profession that industry and government recognise the standards and accreditation of the governing body. With chartered accountants, universal acceptance of the standard that the governing body set means that appointments of CAs centre not on their qualifications and experience, but on their registration with the governing body. One can trace many of the woes of the reputation of HR managers back to a lack of universally accepted standards of qualification, experience and peer recognition that come through professional registration.

Respondents see 'continued concern for professional competence' as imperative. Here, HR practitioners are not only concerned about their own current knowledge but this value indicates a general concern for the competence of practitioners in the profession. It supports the third pillar 'autonomy in practice and the privilege of self-regulation'.

Respondents regarded 'continuing to develop knowledge' and 'keeping up to date' highly. Therefore, structured and continued professional development is a non-negotiable. Professions accept this premise universally. All professions are continually evolving. It is important that currency of knowledge in education, training and continued professional development, as well as new solutions through research, receive constant and vigilant attention.

The continued professional development policy of the South African Board for People Practices describes CPD as 'the systematic, ongoing structured process that human resource professionals undertake to maintain, develop and enhance skills, knowledge and competence both professionally and personally in order to improve performance at work, throughout their working life'.

\section{Discussion}

The qualitative and quantitative analyses lead to the main conclusion of this study: that human resource management meets every one of the criteria the researchers identified. Therefore, one can regard it as a bona fide profession.
The key contribution of this study was that it identified a number of aspects that determine professionalism and isolated the most important elements one should consider when regulating the HR profession.

These conclusions emerge from the values and functions of other major professions and the values and functions of similar HR managing bodies in other countries. One finds significant similarities in all these professional bodies. The researchers also reached these conclusions based on the participation and input by human resource practitioners in South Africa. The four main pillars of professionalism remain the same for all professions.

From the study of four major professions, one can conclude that they have many conduct issues (including values and ethics) in common, although each has unique elements.

The times we live in have also made it more difficult than ever to honour professional commitment. There is, for instance, an interesting correlation between the sentiments the medical profession expressed, that social change has not benefitted the profession, and the one the legal profession articulated, that the influence big corporations exert on them has been detrimental to the ethics of the profession. We are living in a rapidly changing environment and the saying 'adapt or die' has become the motto of the day. Whether professions can maintain the moral fibre of the past is open to question.

The researchers have now examined the question of whether human resource management is a profession in the light of their scrutiny of other major professions. The literature

TABLE 10: Content Validity Ratio (Lawshe) of responsibility towards client or employer.

\begin{tabular}{|c|c|c|c|}
\hline Identifying elements & $N_{e}$ & $N$ & CVR \\
\hline Acting in client's interest & 66 & 77 & 0.7143 \\
\hline Certifying and authorising as personally verified & 52 & 74 & 0.4054 \\
\hline Maintaining and improving integrity & 51 & 75 & 0.3600 \\
\hline Assume responsibility for effect of task & 52 & 75 & 0.3867 \\
\hline Not enticing clients away from colleagues & 50 & 74 & 0.3514 \\
\hline Acting as faithful agent & 62 & 75 & 0.6533 \\
\hline Dedication to providing competent service & 73 & 76 & 0.9211 \\
\hline
\end{tabular}


TABLE 11: Descriptive statistics of responsibility towards the public or society.

\begin{tabular}{|c|c|c|c|c|c|c|}
\hline \multirow[t]{2}{*}{ Identifying elements } & \multicolumn{3}{|c|}{ Descriptives } & \multicolumn{3}{|c|}{ Lawshe frequencies of items } \\
\hline & $N$ & Mean & SD & $\begin{array}{l}\text { Perceived as } \\
\text { 'essential' }\end{array}$ & $\begin{array}{l}\text { Perceived as 'useful } \\
\text { but not essential' }\end{array}$ & $\begin{array}{l}\text { Perceived as 'not } \\
\text { necessary' }\end{array}$ \\
\hline Dedication to service & 78 & 3.8462 & 1.06998 & 53 & 18 & 7 \\
\hline Acceptance of duty & 77 & 3.3377 & 1.08349 & 35 & 24 & 18 \\
\hline Holding paramount the safety, etc. of public & 76 & 3.4605 & 1.22682 & 38 & 22 & 16 \\
\hline Serving with fidelity & 77 & 3.8701 & 1.15109 & 52 & 14 & 11 \\
\hline Promoting the public good & 76 & 3.4605 & 1.23764 & 44 & 14 & 18 \\
\hline $\begin{array}{l}\text { Willingness to subordinate narrow } \\
\text { self-interest }\end{array}$ & 75 & 3.4667 & 1.2875 & 40 & 17 & 17 \\
\hline
\end{tabular}

$\mathrm{SD}$, denotes standard deviation; $N$, denotes number of respondents.

study has recorded the views of eminent writers in this field. They have highlighted the evolving and increasingly important role of human resource management globally. The conclusions that follow seem reasonable:

- human resource management is practised worldwide and is recognised as an integral part of the business environment

- human resource management has formalised its own structures to a greater or lesser extent in the various countries

- human resource management has identified its main elements of practice and a relevant knowledge domain

- human resource management has defined the roles and functions of human resource managers and organised a method of recognising competence that extends from senior to lower levels.

The researchers identified several challenges if HR management is to achieve recognition as a profession:

- society is largely uninformed about the nature of human resource management

- practising HR professionals were unwilling to present themselves for assessment as a prerequisite for professional registration, possibly because they were afraid they would not achieve an acceptable level

- whilst there is a body of knowledge, there is no uniformly or internationally recognised educational path for entry into the profession, as there is with other professions

- HR management has diversely educated professionals who have mastered the body of knowledge of related professions and this makes identifying with differently constituted professions, like industrial psychology, labour law and industrial sociology difficult

- there are various points of entry into the profession from other disciplines and the borders seem extremely permeable

- other disciplines tend to 'dump' unsuccessful managers into the human resource field (Klimoski, 2001), to the detriment of the reputation of HR managers; one cannot control the quality of entrants without entry requirements

- organisations that employ HR practitioners have differing criteria for appointment to HR positions and differing perceptions of the role of HR managers

- an obligation to society does not seem to enjoy the same commitment as it does in the four major international professions of law, medicine, engineering and accounting.

Regulating HR management is necessary. It remains the ideal to self-regulate and work with passionate and totally committed people only. However, this is rarely achievable in a large system.

Minimum standards for regulation will have a profound effect on the quality of the profession. The professional body should concern itself with continually enforcing minimum standards, informally and formally. The profession should continue to pursue the goal of having legislation passed or obtaining a charter for HR management that has national sanction.

The reasons for professionalising include:

- Ethics. Human resource practitioners hold influential positions, are visible and shape the policies that affect every employee from entry to retirement. The leaders in HR management are the architects that facilitate the process of establishing a company's brand (Ulrich \& Smallwood, 2007). Losey et al. (2005, p. 1) argue that 'if human resource managers do not accurately anticipate the future and do not plan appropriately' they affect more than plans, machines, sales and numbers. In fact, 'they touch people's lives'. Mistakes can hardly ever be undone. To put the workforce into the hands of unqualified people is a recipe for disaster.

- The effect of human capital on the bottom line. Boudreau and Ramstad (2007) point out that 'academics and consulting firms provide a barrage of evidence that HR practices correlate with financial performance'.

TABLE 12: Content Validity Ratio (Lawshe) of responsibility towards the public or society.

\begin{tabular}{|c|c|c|c|}
\hline Identifying elements & $N_{e}$ & $N$ & CVR \\
\hline Dedication to service & 53 & 78 & 0.3590 \\
\hline Acceptance of duty & 35 & 77 & -0.0909 \\
\hline Holding paramount the safety, etc. of public & 38 & 76 & 0.0000 \\
\hline Serving with fidelity & 52 & 77 & 0.3506 \\
\hline Promoting the public good & 44 & 76 & 0.1579 \\
\hline Willingness to subordinate narrow self-interest & 40 & 75 & 0.0667 \\
\hline
\end{tabular}


TABLE 13: Descriptive statistics of responsibility for personal work ethic.

\begin{tabular}{|c|c|c|c|c|c|c|}
\hline \multirow[t]{2}{*}{ Identifying elements } & \multicolumn{3}{|c|}{ Descriptives } & \multicolumn{3}{|c|}{ Lawshe frequencies of items } \\
\hline & $N$ & Mean & SD & $\begin{array}{l}\text { Perceived as } \\
\text { 'essential' }\end{array}$ & $\begin{array}{l}\text { Perceived as 'useful } \\
\text { but not essential' }\end{array}$ & $\begin{array}{c}\text { Perceived as 'not } \\
\text { necessary' }\end{array}$ \\
\hline Promoting justice and fairness & 77 & 4.3506 & 0.94265 & 66 & 7 & 4 \\
\hline Avoiding conflict of interest & 74 & 4.0135 & 0.95793 & 52 & 18 & 4 \\
\hline Adopting responsible behaviour & 76 & 4.4211 & 0.75301 & 69 & 6 & 1 \\
\hline Respecting the rights of others & 76 & 4.3684 & 0.877 & 65 & 8 & 3 \\
\hline Maintaining an objective outlook & 75 & 4.28 & 0.84725 & 63 & 10 & 2 \\
\hline $\begin{array}{l}\text { Rendering service in accordance with } \\
\text { standards }\end{array}$ & 77 & 4.4805 & 0.77137 & 69 & 7 & 1 \\
\hline Building a professional reputation & 76 & 4.1711 & 1.08797 & 60 & 9 & 7 \\
\hline $\begin{array}{l}\text { Issuing public statements objectively and } \\
\text { truthfully }\end{array}$ & 75 & 4.12 & 0.97204 & 60 & 10 & 5 \\
\hline Playing a positive and constructive role & 74 & 4.0541 & 0.8897 & 58 & 12 & 4 \\
\hline
\end{tabular}

SD, denotes standard deviation; $N$, denotes number of respondents.

Organisations will increasingly compete by making effective decisions that align with professional practices in the talent market.

- The global village. In The Future of Human Resource Management, Losey et al. (2005) agree that the world is changing in ways that put HR management in the spotlight because of the changing composition of the workforce, rapidly developing technology, increasing globalisation and increased competitiveness.

In HR Competencies, Ulrich et al. (2008) have another list of HR management roles that are emerging:

- talent managers or organisation designers

- culture and change stewards

- strategy architects

- operational executors

- business allies

- credible activists.

Eminent writers in the HR field have confirmed that HR management is a profession that is increasing in importance (Kearns, Ulrich, Losey, Meisinger, Boudreau etc.). However, HR managers in the USA and in Europe have not taken the final and logical step to fully-fledged professionalism. On the other hand, the UK has given royal charter status to the profession (Boudreau \& Ramstad, 2007).

After examining the HR profession internationally, including the work of academics and practitioners, and the work of the South African Board for People Practices in particular, the researchers conclude that there is already an extensive list of the necessary professional elements for recognising HR management as a fully-fledged profession. The human resource function in South Africa has:

- international status and recognition

- an established body of knowledge

- a regulatory body with a track record of stability that is recognised under the South African Qualifications Authority (SAQA) Act

- heraldic registration

- formal registration processes

- a career path that provides for entry at various levels
- registration levels with detailed competency criteria

- post nominal titles for registration levels

- a modern and workable code of conduct

- disciplinary policies and procedures for deregistration

- an electronic CPD process to keep professionals current

- an accredited quality assurance process

- the will to regulate itself.

\section{Conclusion and recommendations for future research}

If one accepts the increasing importance of the HR manager's role in managing human capital and talent, together with the economic imperative for the effective practice of this function, one can infer that the time has come to formalise the professionalisation of HR management. It is important to note that the SAQA act and the National Learner Records Database (NLRD) already list the SABPP as the professional body, and that the SAQA act lists it as the statutory quality assurance body for HR management in South Africa.

Extensive consultations with HR practitioners have clearly indicated that there is an awareness and acceptance of the necessity to regulate. More than that, there is an urgency to achieve this recognition as soon as possible. There is also a growing acceptance in business that professional registration is a benchmark of quality. It is also becoming

TABLE 14: Content Validity Ratio (Lawshe) of responsibility for personal work ethic.

\begin{tabular}{llll}
\hline Identifying elements & $N_{e}$ & $N$ & CVR \\
\hline Promoting justice and fairness & 66 & 77 & 0.7143 \\
Avoiding conflict of interest & 52 & 74 & 0.4054 \\
Adopting responsible behaviour & 69 & 76 & 0.8158 \\
Respecting the rights of others & 65 & 76 & 0.7105 \\
Maintaining an objective outlook & 63 & 75 & 0.68 \\
$\begin{array}{l}\text { Rendering service in accordance with } \\
\text { standards }\end{array}$ & 69 & 77 & 0.7922 \\
$\begin{array}{l}\text { Building a professional reputation } \\
\text { Issuing public statements objectively and }\end{array}$ & 60 & 76 & 0.5789 \\
truthfully & 60 & 75 & 0.6 \\
Playing a positive and constructive role & 58 & 74 & 0.5676 \\
\hline
\end{tabular}

$N_{e}$, denotes number of respondents who indicated 'essential'; $N$, denotes number of respondents; CVR, denotes Content Validity Ratio. CVR values $>0.2$ are significant at $p 0.05$ 
TABLE 15: Descriptive statistics of responsibility for knowledge and skills.

\begin{tabular}{|c|c|c|c|c|c|c|}
\hline \multirow[t]{2}{*}{ Identifying elements } & \multicolumn{3}{|c|}{ Descriptives } & \multicolumn{3}{|c|}{ Lawshe frequencies of items } \\
\hline & $N$ & Mean & SD & $\begin{array}{l}\text { Perceived as } \\
\text { 'essential' }\end{array}$ & $\begin{array}{l}\text { Perceived as 'useful } \\
\text { but not essential' }\end{array}$ & $\begin{array}{l}\text { Perceived as 'not } \\
\text { necessary' }\end{array}$ \\
\hline $\begin{array}{l}\text { Mastering the intellectual skills of the } \\
\text { profession }\end{array}$ & 76 & 4.4342 & 0.75429 & 66 & 9 & 1 \\
\hline $\begin{array}{l}\text { Continued concern for professional } \\
\text { competence }\end{array}$ & 76 & 4.3816 & 0.7297 & 69 & 5 & 2 \\
\hline Recognising personal limitations & 77 & 4.1688 & 0.97876 & 60 & 13 & 4 \\
\hline Continuing to develop knowledge & 78 & 4.3718 & 0.77475 & 68 & 8 & 2 \\
\hline
\end{tabular}

$\mathrm{SD}$, denotes standard deviation; $N$, denotes number of respondents.

more commonplace to find a requirement for registration when one applies for an HR position.

The profession needs the government to endorse the process to make this a national reality. The researchers recommend that the SABPP forges ahead to obtain some form of regulation of HR management in South Africa, if not in legislation then by taking the same route as the CIPD did to formalise through a gazetted chartered council.

The researchers also suggest that human capital managers find a place in the next King Report. All listed companies should appoint professionally registered HR practitioners, at least in their top echelons of human capital managers, as a way of ensuring best practice. The researchers believed that establishing a recognised and uniform standard of competence and professionalism will improve good governance.

The researchers further propose that these practitioners are at least at Chartered HR Practitioner level or Master HR Practitioner level. As with other professions, like accountancy, the practitioners registered at these levels would have qualifications, experience and recognition that their professional body prescribes. They would be accountable, according to a code of conduct, and would need to continue their personal development and to report on this development annually. The researchers also recommend that the Institute of People Management (IPM) and the SABPP together take the idea of accountability to the international stage and make an argument for rationalising standards.

The code of conduct of the SABPP needs to be work-shopped and the board should provide guidance through examples and case studies. This will help the profession to internalise the code. Communication that underlines the importance of setting an example and practising at the highest ethical level needs to reinforce accountability constantly.

The researchers further recommend that tertiary institutions do far more training on ethics than they do currently.

In a constantly changing world, HR managers need to revise and update the content of curricula and check whether the right specialist functions are still acknowledged. HR management functions are constantly being adjusted to fit the environment.

The researchers recommend that, in the light of functions that other countries recognise, and new developments in commerce and industry, that the SABPP review the specialist categories it recognises. It is up to HR managers to define their roles clearly and to help society understand exactly what HR managers do to benefit society as a whole. This would lead to recognition of the value of human resource management and will achieve the approval of the broader society.

Future research can be conducted on the role of managers in informing human resource personnel about the various categories of registration after applicants have obtained tertiary qualifications in the field. The reason is that registration, as a professional in the human resource field, will strengthen the case for professionalising HR management in South Africa further.

\section{Limitations of the study}

The main limitation of the study is the questionnaire. The researchers did not develop the questionnaire from the literature review. A panel of experts in the field of HR management developed it. For this reason, the researchers did not use it as the primary source of data but as the third leg of the triangulation process.

The second limitation was that the response rate to the questionnaire was low.

TABLE 16: Content Validity Ratio (Lawshe) of responsibility for knowledge and skills.

\begin{tabular}{llll}
\hline Identifying elements & $N_{e}$ & $N$ & CVR \\
\hline $\begin{array}{l}\text { Mastering the intellectual skills of the } \\
\text { profession }\end{array}$ & 66 & 76 & 0.7368 \\
$\begin{array}{l}\text { Continued concern for professional } \\
\text { competence }\end{array}$ & 69 & 76 & 0.8158 \\
$\begin{array}{l}\text { Recognising personal limitations } \\
\text { Keeping up to date }\end{array}$ & 60 & 77 & 0.5584 \\
Continuing to develop knowledge & 65 & 77 & 0.6883 \\
\hline
\end{tabular}

$N_{e^{\prime}}$ denotes number of respondents who indicated 'essential'; $N$, denotes number of respondents; CVR, denotes Content Validity Ratio.

CVR values $>0.2$ are significant at $p 0.05$ 


\section{References}

Abdulla, Z., \& Threadgold, T. (2010). Towards the professionalization of public relations in Malaysia: perception management and strategy development. Retrieved November 15, 2010, from http://www.bledcom.com/uploads/papers/ Abdullah_Threadgold.pdf

Armstrong, M. (2000). Human Resource Management Practice. London: Kogan Page Ltd.

Barnhart, P.A. (1994). The Guide to National Professional Certificate Programs. Amherst, Massachusetts: Human Resource Development Press.

Blancero, D., Boroski, J., \& Dyer, L. (1995). Transforming human resource organizations: A field study of future competency requirements. Retrieved October 18, 2010, from http://digitalcommons.ilr.cornell.edu/cgi/viewcontent.cgi?article=1217\&co ntext=cahrswp

Boudreau, J.W., \& Ramstad, P.M. (2007). Beyond HR. Boston: Harvard Business School Press.

Cohen, D.J. (2005). Human Resource Education: A Career-Long Commitment. In M.R Losey, S.R. Meisinger \& D. Ulrich (Eds.). The Future of Human Resource Management, (pp. 63-70). Virginia: John Wiley \& Sons.

Dixon, T. (2006). Corporate governance is an antidote to corruption in companies. Business Day, 5(4), 1-10.

Drucker, P.F. (1995). Managing in a Time of Great Change. USA: Truman Talley/Dutton.

Hancock, B. (2002). Introduction to qualitative research. Retrieved December 02 2008 , from www.trentrdsu.org.uk/cms/uploads/Qualitative\%20Research.pdf

Handy, C. (1997). Leader to Leader. London: SAGE.

Harrison, P. (2007). How does the professional learn to practice? Retrieved November 15, 2010, from http://www.mngt.waikato.ac.nz/ejrot/cmsconference/2007/ proceedings/whereiscriticalhrm/harrison.pdf

Hock, D. (1999). Birth of the Chaordic Age. San Francisco: Berrett-Koehler.

Kvale, S. (1996). Interviews: an introduction to qualitative research interviewing Thousand Oaks: SAGE Publishers.

Klimoski, R. (2001, August). Cautiously Optimistic. Paper presented at the Academy of Management Conference, Atlanta, Georgia.

Lauk, E., \& Pallas, A. (2008). Early development of Estonian journalism as a profession (from late 19th century to 1940). Acta Historica Tallinnesai, 13, 48-67. doi:10.3176/hist.2008.2.03

Lawshe, H. (1975). A quantitative approach to content validity. Personnel Psychology, 28(4), 563-575. doi:10.1111/j.1744-6570.1975.tb01393.x

Lewis, J.W. (2001). Ethics and the Learned Professions. Retrieved October 18, 2010, from www.globalethics.org/files/wp_professions.pdf/20/-

Losey, M.R. (1997). The future HR professional: competency buttressed by advocacy. Human Resource Management, 36(1), 147-50.

Losey, M.R., Meisinger, S., \& Ulrich, D. (2005). The Future of Human Resource Management. New Jersey: John Wiley \& Sons.

Mackey, A., \& Gass, S.M. (2005). Second language research. Methodology and design. London: Routledge.

Maudsley, G., \& Strivens, J. (2000). Promoting professional knowledge, experiential learning and critical thinking for medical students. Medical Education, 34 535-544. doi:10.1046/j.1365-2923.2000.00632.x, PMid:10886636
Meisinger, S. (2006). 2005-2006 Annual Report. Retrieved October 18, 2010, from www.mercyhigh.org/Newsletters/Document3_4a7a7f1530e46.pdf

Muhr, T. (1997). ATLAS.ti. The knowledge workbench. Berlin: Scientific Software Development.

Ndlovu, N. (2006). Good governance simply means to lead by example. The Star. Retrieved October 18, 2010, from http://www.highbeam.com/ doc/1G1-152474920.html

Pellegrino, E.D. (2002). Professionalism, profession and virtue. The Mount Sina Journal of Medicine, 69(6), 378-384. PMid:12429956

Robert, L.W. (2004). Influence of Ethical Safeguards on Research Participation: Comparison of Perspectives of People with Schizophrenia and Psychiatrists. The American Journal of Psychiatry, 161, 2309-2311. doi:10.1176/appi. ajp.161.12.2309, PMid:15569905

Rose, R. (2006). Institute plans to introduce title of 'chartered director'. Business Day, Retrieved October 18, 2010, from http://allafrica.com/stories/200610020711. html

Temkin, S. (2009). King III: sets worldwide bar on corporate guidance. Business Day, Retrieved September 03, 2009, from http://www.businessday.co.za/Articles/ Content.aspx?id=80459

Transparency International. (2006). TI Corruption Perceptions Index. Retrieved October 18, 2010, from http://www.transparency.org/policy research/surveys indices/global/cpi

Transparency International. (2007). Report on the Global Corruption Barometer 2007. Retrieved October 18, 2010, from http://www.ethicsworld.org/ publicsectorgovernance/PDF\%20links/BAROMETER.pdf

Trochim, W.M.K. (2006). Qualitative measures. Retrieved October 18, 2010, from http://www.socialresearchmethods.net/kb/qual.php

Ulrich, D., \& Brockbank, W. (2005). The HR Value Proposition. Boston: Harvard Business School Press.

Ulrich, D., Brockbank, W., Johnson, D., Sandholtz, K., \& Younger, J. (2008). HR Competencies: Mastery at the Intersection of People and Business. Virginia: Society For Human Resource Management.

Ulrich, D., \& Eichinger, R.W. (1998). Delivering HR with an attitude. Retrieved October 18, 2010, from http://www.kornferryinstitute.com/files/pdf1/HRwithanattitude. pdf

Ulrich, D., \& Smallwood, N. (2007). Leadership Brand. Boston: Harvard Business School Press.

Ungerer, M., Herholdt, J., \& Uys, K. (2006). Leveraging knowledge-based Assets - The New Value Equation to Create Competitive Advantage. Johannesburg: Knowres.

Van Rensburg, A.H. (2009). Human resource management as a profession in South Africa. Unpublished MPhil dissertation. Pretoria: University of Pretoria.

Wilensky, H.L. (1964). The professionalization of everyone? American Journal of Sociology, 70.

Williams, B., Onsman, A., \& Brown, T. (2009). From stretcher-bearer to paramedic: the Australian paramedics' move towards professionalisation. Journal of Emergency Primary Health Care, 7(4), 1-12.

Williams, N.S.W. (1997). Engineer Ethics. Engineer Mentor: published for Engineersin-Training, 1(1), 10-25. 